\title{
Isolation and Identification of Heterorhabditis bacteriophora from Tea Plantation of Assam
}

\author{
Bharath Amuri $^{1 *}$, Gitanjali Devi ${ }^{1}$, B. N. Choudhury ${ }^{1}$, P. Debnath ${ }^{2}$ and Diganta Bora ${ }^{3}$ \\ ${ }^{1}$ Department of Nematology, ${ }^{2}$ Department of Plant pathology, ${ }^{3}$ Department of Tea Husbandry \\ and Technology, Assam Agricultural University Jorhat, Assam, India \\ *Corresponding author
}

\begin{abstract}
A B S T R A C T
A total 200 soil samples were collected from tea plantation areas of district, Jorhat, Assam and were assessed for entomopathogenic nematodes using the Galleria baiting technique. Out of 200 soil samples, EPN was found in 1 soil sample collected from Tea plantation, Chetiagaon, Jorhat and designated as EPN-H-1. Morphological and morphometrical characters were used for the identification of nematode isolate. The measurements were expressed in \% ratios and Means \pm SD ranges. The IJ of EPN-H-J-l showed close similarity with $H$. bacteriophora with respect to head shape, ratio $\mathrm{b}, \mathrm{D} \%$ and $\mathrm{E} \%$, but exhibited minor differences from the type measurements by having lower tail length $(82$ vs. 91). The males of this isolate showed close similarity with H. bacteriophora with respect to head shape, anal body width, gubernaculum length but exhibited minor differences from the type measurements by having higher esophagus length (107 vs. 103) and tail length (34 vs. 28). The hermaphroditic and amphimictic females of this isolate exhibited differences from the type measurements by having lower body length, lower body width and lower anal body width which are considered as intraspecific variations of H. Bacteriophora. Comparative analysis revealed that an EPN-H-1 isolate belong to the Heterorhabditis bacteriophora as earlier described by Poinar, 1976 from Brecon, South Australia in respect of body length, body width, tail length etc.
\end{abstract}

\section{Introduction}

Nematodes which are capable of killing, hampering the insect development and carrying out at least one stage of their life cycle in the host are called insect pathogenic nematodes i.e EPNs (entomopathogenic nematodes). Entomopathogenic nematodes contain mainly two genera Steinernema and Heterorhaditis in the family Steinernematidae and Heterorhabditidae of the order Rhabditida. They are obligate in nature and the widely disperse dispersed in the soils of different ecosystem.

They have an ability to act as best biocontrol agents against insect pests as compared to the bacterial and fungal bioagents. Recently, EPNs are considered as one of the nonchemical alternatives control strategy. 
The $3^{\text {rd }}$ stage juvenile act as an infective in nature and which is free-living in the soil, non-feeding, encased in a double cuticle with closed mouth and anus and capable of surviving for several weeks in the soil, before infecting a new host individual. It has ability to enter in the insect host through natural opening or actively penetrated through their cuticle. These juveniles mainly feed on the hemocoel of insect and they play strategy called as trogan horse in which they carry a Photorhabdus bacterium as symbionts in their intestine and the cuticle (Kaya and Gaugler, 1993; Torres-Barragan et al., 2011; Zhang et al., 2008, 2009, 2012).

After entering in the insect blood the juveniles released the bacteria and both overcome the insect immune system and killed the host within 24-48 hours of post infection (Adams and Nguyen, 2002). The life cycle of heterorhabditidis similar to that of steinernematids except for the fact that the IJs always develop into self-reproducing hermaphrodites (Poinar, 1990). Strauch et al., (2000) observed that offspring of the firstgeneration hermaphrodites can either develop into amphimictic adults or into automictic hermaphrodite both can occur simultaneously. The cycle from entry of IJs into a $3^{\text {rd }}$ stage until emergence of new IJs is dependent on temperature and varies for different species and strains.

Generally, life-cycle of EPNs (infective juvenile penetration to infective juvenile emergence) is completed within 12-15 days. The optimum temperature for growth and reproduction of nematodes is between $25^{\circ} \mathrm{C}$ and $30^{\circ} \mathrm{C}$. They show their variations in respect of morphology, reproduction, infectivity, host range and conditions for survival under different environment conditions (Bedding, 1983). In the northeastern region of India, a few surveys against EPNs have been conducted in various habitats but and no survey has been conducted to document the occurrence of EPNs in tea habitats. So that a study was undertaken to isolate and identify EPNs from tea infested by $H$. theivora and A. bipunctata under Assam condition.

\section{Materials and Methods}

\section{Survey and sample collection}

A survey was undertaken in the tea plantation areas of Jorhat district of Assam for the presence of entomopathogenic nematodes (EPNs) during the year 2017-18. A total of 200 soil samples were collected randomly during the period Nov 2017 to Nov 2018. Each soil sample, weighing approximately 1 $\mathrm{kg}$, was a composite of five random subsamples collected at least $100 \mathrm{~m}$ apart at each site at a depth of 10-20 cm in an area of $20 \mathrm{~m}^{2}$. Information regarding date of sampling, and soil type along with GPS (Global Positioning System) location was recorded. Samples were packed in polythene bags and maintained at refrigerated conditions in the laboratory for further processing. The soil was thoroughly mixed on a plastic sheet and half of each sample was used for extraction of EPNs.

\section{Rearing of bait insect}

Greater wax moth, Galleria mellonella (Lepidoptera: Pyralidae) larvae is used as a bait insect for the trapping of EPNs. $G$. mellonella was collected from the Department of Entomology, AAU, Jorhat. The culture of $G$. mellonella was maintained on a semisynthetic diet in the P.G laboratory, Department of Nematology, AAU, Jorhat (Plate 4).All solid ingredients, viz., corn flour (400 gm), wheat bran (150 gm), wheat flour (200 gm), wheat germ (50 gm), yeast and milk powder (200 gm) were mixed thoroughly in a clean flat plastic tray. 
Honey and glycerine (200 gm) dissolved in lukewarm water (200 gm) was added slowly to the solid mixture followed by the addition of streptomycin sulphate $(100 \mathrm{gm})$. The mixture was kneaded thoroughly until semisolid light yellow coloured dough was obtained. This diet was transferred to $2 \mathrm{~L}$ capacity wide mouth jars and filled up to $1 / 4$ th of its volume. They were inoculated with 20-25 egg masses (each containing 500 eggs).

The jars were covered with white muslin cloth, secured by rubber band and incubated at $25^{\circ} \mathrm{C}$ in the BOD incubator. Incubated eggs hatched within a week, emerging neonates fed voraciously and underwent 5 moults before pupation in 25 days. Pupae were transferred to a clean adult rearing cage. Adult moths emerged from pupae within 10-12 days. The emerging moths were collected every morning, sorted into males and females based on their size and shape and released into the egg laying chamber in the ratio of 1:6 (male : female).

Tissue papers made into folds were hanged inside the chamber for egg laying. Adults were feed on $20-30 \%$ honey solution through cotton wick in a small plastic dish. Within few days of mating, females laid eggs on the tissue paper. These eggs were then transferred to a fresh culture medium kept at $28^{\circ} \mathrm{C}$ in the BOD incubator for next generation. The $4^{\text {th }}$ instar larvae were used for baiting.

\section{Extraction of entomopathogenic nematodes (EPNs) from soil samples}

Entomopathogenic nematodes were isolated from the soil samples by the method described by Fan and Hominick (1991) with larvae of the greater wax moth (Galleria mellonella). Before processing, soil samples were homogenized and then baited. Ten last instar larvae of $G$. mellonella were released into the plastic container containing $200 \mathrm{~g}$ of soil sample. Baited samples were stored in the dark at room temperature. Samples were inverted at regular intervals and monitored for mortality up to 7-8 days. Insect cadavers from each soil sample were taken out and examined for infection. Collected G. mellonella larvae were transferred to White traps (White, 1927) and infected cadavers were placed on a $9 \mathrm{~cm}$ Whatman No.1 filter paper over a small Petri dish $(50 \mathrm{~mm} \times 17 \mathrm{~mm})$ which was then placed in bigger Petri dish $(100 \mathrm{~mm} \times 20 \mathrm{~mm})$ containing water. IJs recovered for the 5-12 following days were collected. IJs that emerged were pooled from each sample and used to infect fresh last instars of $G$. mellonella larvae to verify their pathogenicity and allow the production of progeny for identification at the genus level, considering the characteristic colour of the G. mellonella cadavers (Kaya and Stock, 1997).

\section{Isolation of adults}

In nature, the adults of first and second generation are found only in the haemocoel of cadaver; hence they were extracted by dissection in Ringer's solution. The dissection was done at 2-4 and 4-5 days after inoculation (DAI) for recovering the first generation and second-generation adults, respectively. The recovered nematodes were kept in clean ringer's solution for further processing.

\section{Processing of nematodes}

Third stage infective juveniles in sterile distilled water and freshly dissected out first and second-generation adults in Ringer's solution were killed and fixed by pouring equal volumes of hot tri-ethanolamine formalin (TAF) fixative over the EPN suspension (Kaya and Stock,1997). After 24 hrs, the specimens were handpicked individually and transferred to $100 \%$ TAF and fixed for a week. 
Killed and fixed nematodes were further processed with Seinhorst's slow glycerol dehydration method (Seinhorst, 1959). Permanent mounts were prepared by transferring the nematodes to a drop of anhydrous glycerin on a clean glass slide supported by radially placed 3 small pieces of glass wool supports with thickness approximately equal to the diameter of the nematode to prevent flattening of specimens.

The slides were sealed with paraffin wax and labelled with adequate information including locality, slide number, sex and stage of nematode.

\section{Light microscopic studies}

The permanent slides were examined for detailed morphological characters and body dimensions were studied using de Man's formula (De Man, 1880) and additional ratios to establish their taxonomic identity.

The morphological identification was performed on the basis of characters of third stage infective juveniles and male individuals (Poinar, 1976; Poinar and Georgis, 1990; Nguyen and Smart, 1995; Stock et al., 2002).

\section{Morphological characters}

The following morphological characters were taken into consideration for identification at species level.

(a) Shape of head

(b) Presence or absence of epiptygma

(c) Shape and size of spicules

(d) Shape and size of gubernaculum

(e) Presence or absence of post anal swelling in adult females

(f) Tail shapes of both adults and infective juveniles

(g) Presence or absence of mucron in adults of both sexes

\section{Morphometrical measurements}

In addition to the morphological characters, morphometric measurements also have taxonomic significance in differentiation of species. Morphological characters of 20 specimens each of infective juveniles, males and females of first and second generation were observed. Morphological observations and quantitative measurements were made by advanced stage compound microscope (Olympus).

\section{Liner body dimensions recorded were as follows}

\author{
Body length (L) \\ Body width (W) \\ Oesophageal length (ES) \\ Distance from anterior end to excretory \\ pore (EP) \\ Distance from anterior end to nerve \\ ring (NR) \\ Spicule length (SL) \\ Gubernaculums length (GL) \\ Anal body width (ABW) \\ Tail length (T)
}

\section{The following ratios were computed}

Ratio a = Body length/Greatest body width

Ratio $b=$ Body length/Oesophageal length

Ratio c = Body length/Tail length

$\mathrm{V}=$ Distance of vulva from anterior end/Body length $\times 100$

$\mathrm{D} \%=$ Distance from anterior end to excretory pore / Oesophageal length $\times 100$

$\mathrm{E} \%=$ Distance from anterior end to excretory pore/Tail length $\times 100$

SW\% $=$ Spicule length/anal body with $\times 100$

GS\% = Gubernaculum length/ Spicule length $\times 100$

\section{Comparison with known species}

The morphological character and body 
dimension of Heterorhabditis sp. identified in the present study were compared with the original descriptions of known species. Variations in the morphometrical characters of the existing species were recorded and described.

\section{Results and Discussion}

A random survey was conducted for the natural occurrence of EPNs during 2017-18 from tea plantation area of the district, Jorhat, Assam. A total of 200 samples were collected from Experimental farm for tea plantation crops, Section-4, 10, 19 AAU, Experimental farm for plantation crops, Section-14 AAU, Jorhat, Experimental Farm, Tocklai Tea Research Station and Chetiagaon, Jorhat. Survey data revealed that out of 200 samples, 1 sample was positive for EPN with 1 sample containing Heterorhabditis sp. (0.5\%) (Table.1). One heterorhabditid isolate designated as EPN-H-1 was isolated from rhizosphere of tea from Chetiagaon, Jorhat. Morphological and morphometrical characters were used for the identification of nematode isolates.

Morphological and morphometrical studies of different life stages (infective juveniles, adults) of EPN-H-J-1 revealed that it is closely resemble with Heterorhabditis bacteriophora (Poinar, 1975) in most of the characters.The head of the third-stage infective juvenile (IJ) bears dorsal tooth with mouth and anus is closed. Stoma appears as a closed chamber. The head is with sheath (cuticle of second-stage juvenile). Esophagus and intestine are reduced. The excretory pore is posterior to nerve ring. The tail is long, pointed and covered with a sheath. The male of second generation had slightly round head. They possess a tubular stoma and pharynx with a cylindrical corpus. The isthmus is distinct with a globose basal bulb and a prominent valve. The nerve ring surrounding the isthmus is located near the basal bulb. The excretory pore is located near the middle of the basal bulb. The reproductive structure is monarchic and anteriorly reflexed. The spicules are paired, symmetrical and separate, with pointed tips, slightly curved ventrally. The gubernaculum is flat and narrow. Bursa is peloderan, open, with nine pairs of genital papillae. Tail is pointed. The hermaphroditic female of first generation body curved ventrally when heat-killed. Head region a slightly rounded.

They possess a tubular stoma and pharynx with a cylindrical corpus.The isthmus is distinct and short. Nerve ring surrounding isthmus is just anterior to basal bulb. Basal bulb often surrounded by anterior portion of intestine. Execratory pore is posterior to the basal bulb. Gonads are amphidelphic and reflexed. Vulva is near to the mid-body. Tail is pointed. Tail is longer than anal body width and conoid with pointed terminus. Anal region is slightly protruding.

The amphimictic females of second generation body are ventrally curve when heat-killed, smaller in size than hermaphroditic female. Head region is sub conical. They possess a tubular stoma and with a cylindrical corpus. The vulva is not protrude outward and is surrounded by a hard deposit. Anal region is slightly protruding.

The IJ of EPN-H-J-1 showed close similarity with $H$. bacteriophora with respect to head shape, ratio $\mathrm{b}, \mathrm{D} \%$ and $\mathrm{E} \%$, but exhibited minor differences from the type measurements by having lower tail length (82 vs. 91) (Table 3). The males of this isolate showed close similarity with $H$. bacteriophora with respect to head shape, anal body width, gubernaculum length but exhibited minor differences from the type measurements by having higher esophagus length (107 vs. 103) and tail length (34 vs. 
28). The hermaphroditic and amphimictic females of this isolate exhibited differences from the type measurements by having lower body length, lower body width and lower anal body width which are considered as intraspecific variations of $H$. bacteriophora (Table 3).

A total of one isolate of entomopathogenic nematodes from 200 soil samples collected from Tea plantation areas of district Jorhat, Assam with a per cent recovery of $0.5 \%$. EPN distribution depends on temperature, precipitation and soil type and is closely related to vegetation type and presence of insect host (Nielsen and Philipsen, 2003 and Puza and Mracek, 2005). The soil is sandy or sandy loam with a good amount of organic matter. The nematode presence and abundance were low in different tea fields of most of the sampling site. Although EPN was recorded at a low rate in present study, one isolate of Heterorhabditis bacteriophora $(0.5 \%)$ was recorded.

It may be resulted due to condition of the crop land in terms of irrigation of the field, where the temperature and the soil moisture was suitable for their persistence. One reason for the low recovery rate obtained in the present study, could be the fact that only one insect, Galleria mellonella, was used as bait insect may not be the appropriate host for all EPN species (Kary et al., 2009).

Table.1 Occurrence of Entomopathogenic nematodes in tea plantation areas of district, Jorhat, Assam

\begin{tabular}{|c|c|c|c|c|c|c|}
\hline \multirow[t]{2}{*}{ Locality } & \multirow{2}{*}{$\begin{array}{l}\text { No. of } \\
\text { samples }\end{array}$} & \multirow{2}{*}{$\begin{array}{l}\text { No. of } \\
\text { +ve } \\
\text { samples } \\
\text { for } \\
\text { EPN }\end{array}$} & \multirow[t]{2}{*}{ Crop } & \multicolumn{2}{|l|}{ EPN isolate } & \multirow{2}{*}{$\begin{array}{l}\text { Latitude, } \\
\text { Longitude }\end{array}$} \\
\hline & & & & $\begin{array}{l}\text { Heterorhabditis } \\
\text { sp. }\end{array}$ & $\begin{array}{c}\text { Frequency of } \\
\text { occurrence (\%) }\end{array}$ & \\
\hline $\begin{array}{l}\text { Experimental } \\
\text { farm for } \\
\text { plantation crops, } \\
\text { Section-4,10,19 } \\
\text { AAU, Jorhat }\end{array}$ & 50 & 0 & Tea & & & \\
\hline $\begin{array}{l}\text { Experimental } \\
\text { farm for } \\
\text { plantation crops, } \\
\text { Section-14 AAU, } \\
\text { Jorhat }\end{array}$ & 50 & 0 & Tea & & & \\
\hline $\begin{array}{l}\text { Experimental } \\
\text { Farm, Tocklai } \\
\text { Tea Research } \\
\text { Station }\end{array}$ & 50 & 0 & Tea & & & \\
\hline Chetiagoan & 50 & 1 & & EPN-H-J-1 & 0.5 & $\begin{array}{l}26^{\circ} 71^{\prime} 36.59^{\prime \prime} \mathrm{N} \\
94^{\circ} 19^{\prime} 79.81^{\prime \prime} \mathrm{E}\end{array}$ \\
\hline Total & 200 & 1 & & & 0.5 & \\
\hline
\end{tabular}


Table.2 Morphometrics of Heterorhabditis sp. (EPN-H-J-1) infective juveniles and second generation male in comparison with original description of Heterorhabditis bacteriophora

\begin{tabular}{|c|c|c|c|c|c|}
\hline Character & $\begin{array}{c}\text { Heterorhabditis sp. } \\
\text { (EPN-H-J-1 ) (IJ) } \\
(n=40)\end{array}$ & $\begin{array}{c}\text { Type measurement } \\
\text { H. bacteriophora } \\
\text { (IJ) (Poinar,1976) } \\
(\mathrm{n}=15)\end{array}$ & $\begin{array}{c}\text { Type measurement } \\
\text { H. bacteriophora } \\
\text { (IJ) } \\
\text { (Poinar, 1990) } \\
(\mathrm{n}=25)\end{array}$ & $\begin{array}{c}\text { Heterorhabditis sp. } \\
\text { (EPN-H-J-1) } \\
\text { (Male) } \\
(\mathbf{n}=20)\end{array}$ & $\begin{array}{c}\text { Type } \\
\text { Measurement of } \\
\text { H. bacteriophora } \\
\text { (Male) } \\
\text { (Poinar, 1976) } \\
(n=15)\end{array}$ \\
\hline Body length (L) & $\begin{array}{c}542.57 \pm 42.339 \\
(483-624)\end{array}$ & $\begin{array}{c}570 \\
(520-600)\end{array}$ & $\begin{array}{c}558 \\
(512-671)\end{array}$ & $\begin{array}{c}842.4 \pm 63.9 \\
(760-980)\end{array}$ & $\begin{array}{c}820 \\
(780-960)\end{array}$ \\
\hline Body width (W) & $\begin{array}{l}23.75 \pm 5.278 \\
\quad(14-30)\end{array}$ & $\begin{array}{c}24 \\
(21-31)\end{array}$ & $\begin{array}{c}23 \\
(18-31)\end{array}$ & $\begin{array}{l}46.85 \pm 3.498 \\
(42-53)\end{array}$ & $\begin{array}{c}43 \\
(38-46)\end{array}$ \\
\hline $\begin{array}{l}\text { Anterior end to excretory } \\
\text { pore (EP) }\end{array}$ & $\begin{array}{l}98.2 \pm 6.680 \\
(86-108)\end{array}$ & $\begin{array}{c}104 \\
(94-109)\end{array}$ & $\begin{array}{c}103 \\
(87-110)\end{array}$ & $\begin{array}{c}119.25 \pm 9.64 \\
(106-132)\end{array}$ & $\begin{array}{c}121 \\
(114-130)\end{array}$ \\
\hline $\begin{array}{l}\text { Anterior end to nerve ring } \\
\text { (NR) }\end{array}$ & $\begin{array}{c}84.7 \pm 5.816 \\
(76-94)\end{array}$ & $\begin{array}{c}83 \\
(81-88)\end{array}$ & $\begin{array}{c}85 \\
(72-93)\end{array}$ & $\begin{array}{c}75.6 \pm 3.73 \\
(71-82)\end{array}$ & $\begin{array}{c}72 \\
(65-81)\end{array}$ \\
\hline $\begin{array}{l}\text { Anterior end to esophagus } \\
\text { base (ES) }\end{array}$ & $\begin{array}{l}118.325 \pm 13.00 \\
(96-135)\end{array}$ & $\begin{array}{c}125 \\
(119-130)\end{array}$ & $\begin{array}{c}125 \\
(100-139)\end{array}$ & $\begin{array}{l}107.35 \pm 6.68 \\
\quad(97-118)\end{array}$ & $\begin{array}{c}103 \\
(99-105)\end{array}$ \\
\hline Testis reflection & - & - & - & $\begin{array}{c}81.2 \pm 5.094 \\
(74-90)\end{array}$ & $\begin{array}{c}79 \\
(59-87)\end{array}$ \\
\hline Tail length(T) & $\begin{array}{c}82.05 \pm 8.661 \\
(64-92)\end{array}$ & $\begin{array}{c}91 \\
(83-99)\end{array}$ & $\begin{array}{c}98 \\
(83-112)\end{array}$ & $\begin{array}{c}34.2 \pm 2.44 \\
(31-38)\end{array}$ & $\begin{array}{c}28 \\
(22-36)\end{array}$ \\
\hline $\begin{array}{l}\text { Anal body width } \\
\text { (ABW) }\end{array}$ & $\begin{array}{c}16.475 \pm 3.219 \\
(9-21)\end{array}$ & - & - & $\begin{array}{c}22.05 \pm 1.09 \\
(19-23)\end{array}$ & $\begin{array}{c}23 \\
(22-25)\end{array}$ \\
\hline Ratio $\mathbf{a}=(\mathrm{L} / \mathrm{W})$ & $\begin{array}{c}24.089 \pm 6.303 \\
(16-40)\end{array}$ & $\begin{array}{c}25 \\
(17-30)\end{array}$ & $\begin{array}{c}25 \\
(17-30)\end{array}$ & - & - \\
\hline Spicule length (SL) & - & - & - & $\begin{array}{c}42.75 \pm 3.66 \\
(38-50)\end{array}$ & $\begin{array}{c}40 \\
(36-44)\end{array}$ \\
\hline Gubernaculum length (GL) & - & - & - & $\begin{array}{c}23.05 \pm 2.45 \\
(28-19)\end{array}$ & $\begin{array}{c}20 \\
(18-25)\end{array}$ \\
\hline $\mathrm{D} \%=(\mathrm{EP} / \mathrm{ES}) \times 100$ & - & - & $\begin{array}{c}84 \\
(76-92)\end{array}$ & $\begin{array}{c}111.38 \pm 10.28 \\
(96.4-127.8)\end{array}$ & 117 \\
\hline $\mathrm{SW} \%=\mathrm{SL} / \mathrm{ABW} \times \mathbf{1 0 0}$ & - & - & - & $\begin{array}{c}194.35 \pm 19.44 \\
(165-238)\end{array}$ & 174 \\
\hline GS \% $=$ GS/SL $\times 100$ & - & - & - & $\begin{array}{c}54.2 \pm 6.90 \\
(44-68)\end{array}$ & 50 \\
\hline
\end{tabular}

Measurements in $\mu \mathrm{m}$ and in the form: mean $\pm \mathrm{SD}$ (range) 
Table.3 Morphometrics of Heterorhabditis sp. (EPN-H-J-1) hermaphroditic and amphimictic female in comparison with original description of Heterorhabditis bacteriophora

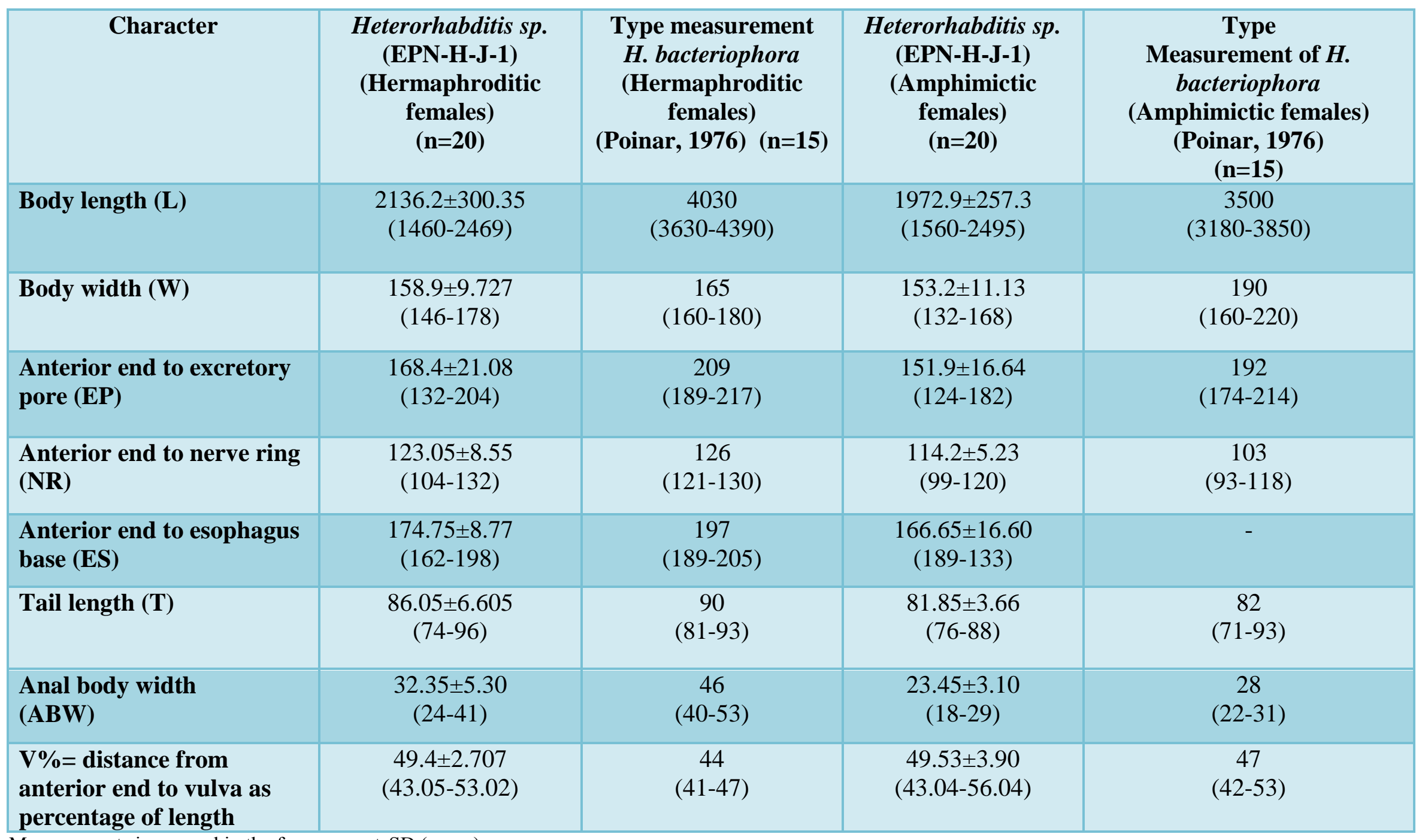

Measurements in $\mu \mathrm{m}$ and in the form: mean \pm SD (range) 


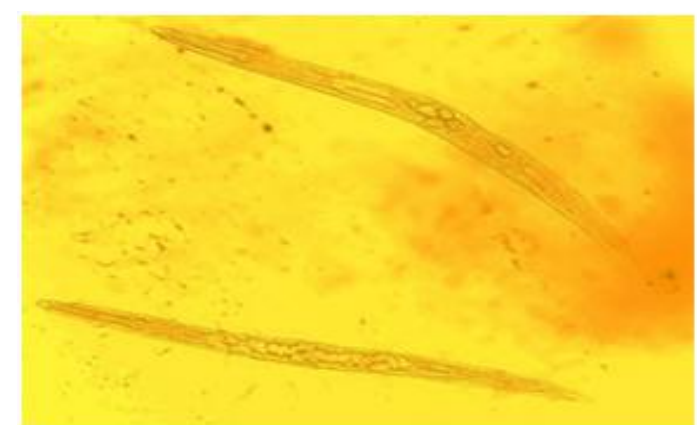

Figure.1 Hermaphroditic female of Heterorhabditis bacteriophora

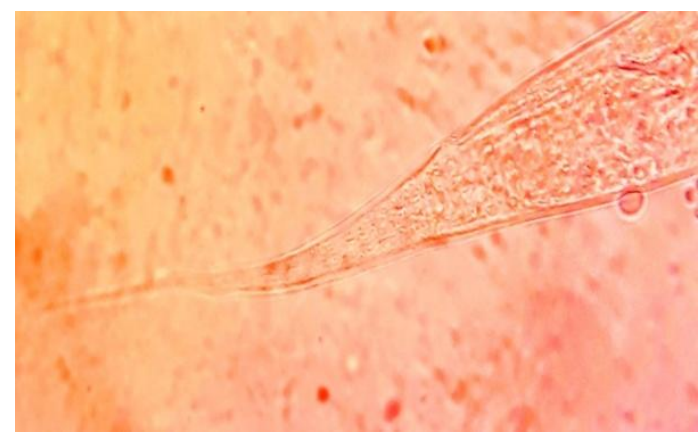

Figure.3Tail region of Hermaphroditic female of Heterorhabditis bacteriophora

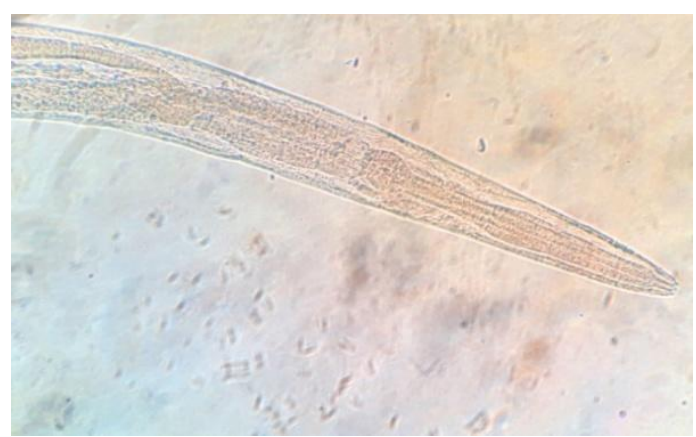

Figure.2 Oesophagus of Hermaphroditic female of Heterorhabditis bacteriophora

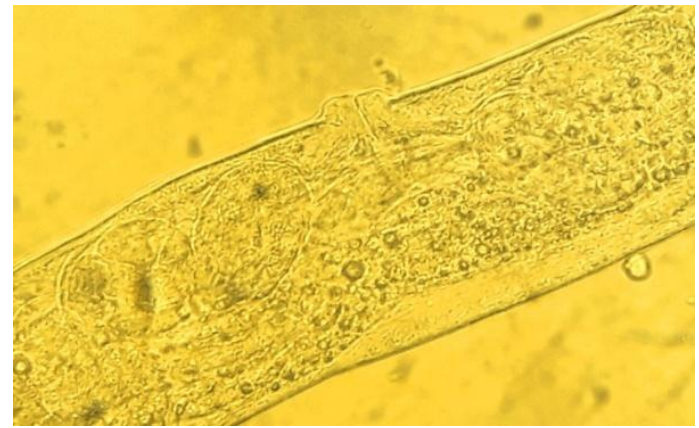

Figure.4 Vulva of Hermaphroditic female of Heterorhabditis bacteriophora

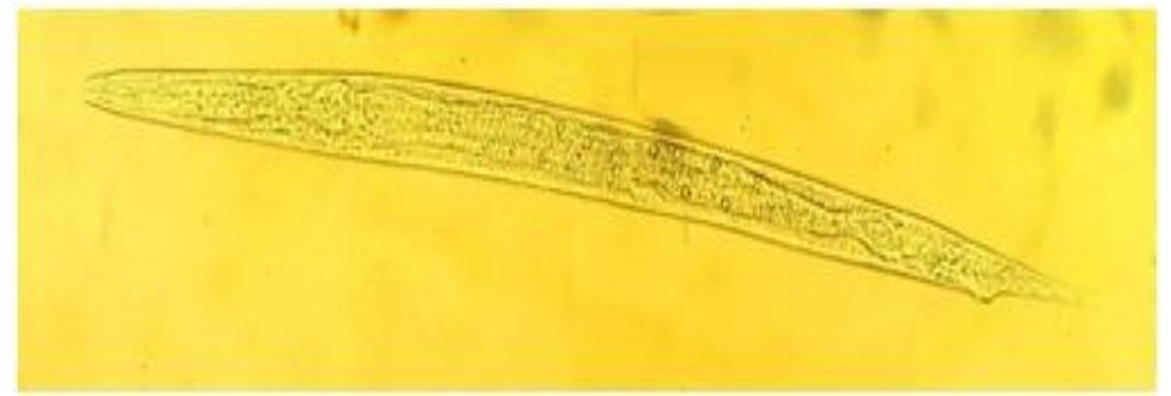

Figure.5 Infective juveniles of Heterorhabditis bacteriophora

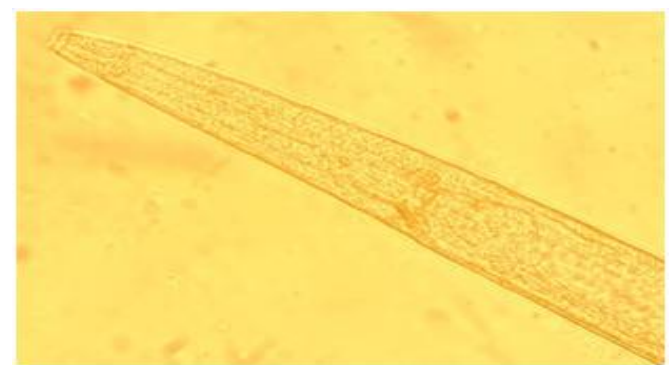

Figure.6 Anterior part of Amphimictic female of Heterorhabditis bacteriophora

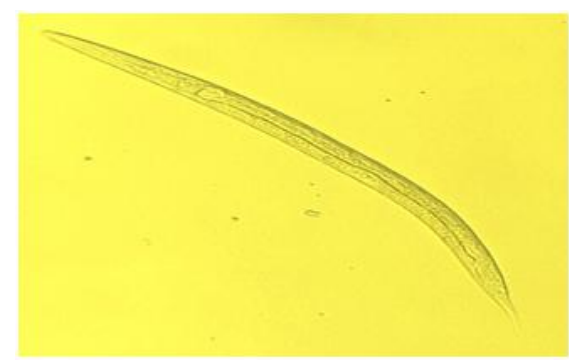

Figure.7 Amphimictic female of Heterorhabditis bacteriophora 


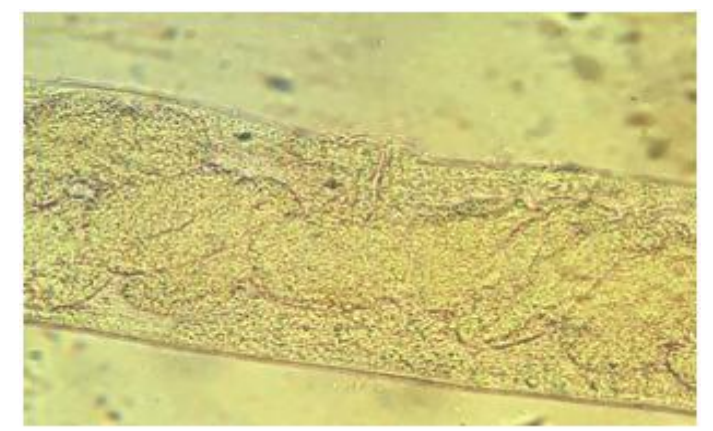

Figure.8 Vulva of Amphimictic female of Heterorhabditis bacteriophora

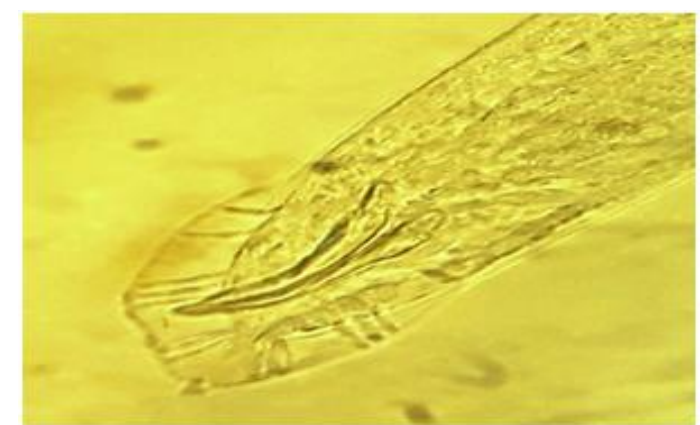

Figure.9 Spicule of Heterorhabditis bacteriophora

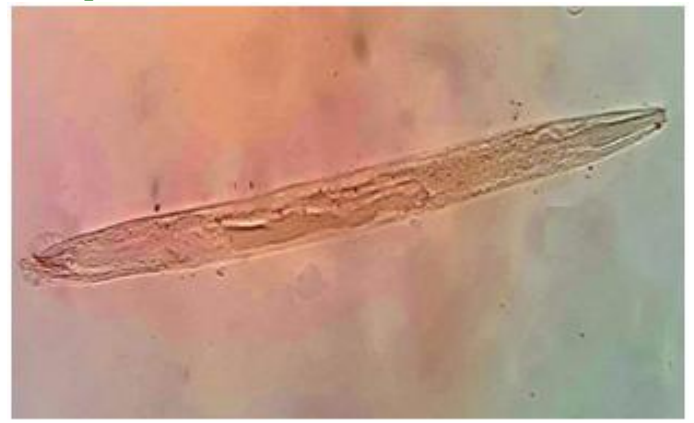

Figure.10 Male of Heterorhabditis bacteriophora

Furthermore, the choice of sampling sites may contribute to difference in EPN recovery percentage (Mracek et al., 2005). Lower percentage of EPNs probably also due to chemical control of insect pest in tea fields which partially reduces the abundance of natural biocontrol agents. However this low recovery percentage is not unusual, and it has already been reported from other surveys (Hazir et al., 2003; Kary et al., 2009).

The EPN isolate positive soil samples were from sandy loam soil and this finding was in agreement with findings of the surveys conducted by Ambika and Sivakumar (2000), which revealed that the occurrence of EPNs was more in light soils like sandy loam, sandy, loamy sand, and loam soil rather than in heavy soils. However, EPNs are present in heavy soils like clay soil also as recorded by Shyamprasad et al., (2001) and Sosamma and Rasmi (2002) in the South Andaman and Kerala, respectively. In Sri Lanka, Heterorhabditis sp. was reported to be restricted to sandy soils within $100 \mathrm{~m}$ of the sea (Amarsinghe et al., 1994). The heterorhabditid isolate was similar to $H$. bacteriophora in original description with respect to third stage infective juvenile in characters like greatest width; distance from anterior end to excretory pore; distance from anterior end to pharynx base; body width at anus; ratio a; ratio $\mathrm{b}$; ratio $\mathrm{c} ; \mathrm{D} \% ; \mathrm{E} \%$. However, the isolate showed variation in body length of IJs (542 vs.570) and tail length (82 vs. 91), Variation also observed with respect to adult stage of both male and female generations in some characters like body length, position of pharynx, position of excretory pore, tail length, spicule length and gubernaculum length, etc.

Nguyen et al., (1995) observed variation in body length, position of excretory pore, tail length and value of $\mathrm{E} \%$ of $H$. bacteriophora in relation to time of harvest. It was observed that body length of infective juvenile was 605 um $(579 \mu \mathrm{m}-634 \mu \mathrm{m})$ on 3rd day of harvest whereas body length 565nm (524 $\mu \mathrm{m} 604$ $\mu \mathrm{m})$ on 15 th day of harvest. In the present 
investigation the third stage IJs were obtained when they emerged from the cadavers after 7 to 10 days. Devi et al., (2016) reported occurrence of $H$. bacteriophora from white grub infested areas of Majuli, Assam.

They exhibited minor differences in morphometrical studies of $H$. bacteriophora from the type measurements by having higher body length of IJs (572 vs. 570), body width (26 vs. 24) position of nerve ring (84 vs. 83).Identification was confirmed using infective juveniles and males because morphology of females and hermaphrodites vary with the nematode generation in the insect (Gaugler, 1990; Wright, 1990). Poinar (I976) isolated and described $H$. bacteriophora from Brecon, South Australia.

The nematode was isolated from the body cavity of Heliothis punctigera Hall (Noctuidae: Lepidoptera). H. bacteriophora is highly mobile, responding to chemical signals from the host, and being adapted to infect less mobile insect that are found in lower soil layers (Ishibashi, 2002). H. bacteriophora is distributed in America, Southern and Central Europe, Australia and East Asia (Hominick et al., 1996). In Europe it has been reported from Spain, Italy, Moldova, Hungary, Southern France (Smits et al., 1991), the Azores, Switzerland (Hominick, 2002), South Russia (Ivanova et al., 2000), the European part of Turkey (Hazir et al., 2003) and Slovenia (Laznik et al., 2009), $H$. bacteriophora isolates were found in neutral (vertisol) or acidic (oxysol) soils incrop lands, orchards, and woodland habitats in Guadeloupe (Grande Terre, Basse Terre). $H$. bacteriophora was reported from India by Sivakumar et al., (1989) and Hussaini et al., (2001).

\section{References}

Adams, B.J. and Nguyen, K.B. (2002). Taxonomy and systematics. In:
Entomopathogenic nematology, Gaugler, A. (ed.) CABI Publishing, Wallingford: UK, pp. 1-33.

Amarasinghe, L.D.; Hominick, W.M.; Briscoe, B.R. and Reid, A.P. (1994). Occurrence and distribution of entomopathogenic nematodes in Sri Lanka. Journal of Helminthology. 68: $277-286$.

Ambika, S. and Sivakumar, C.V. (2000). Natural occurrence of entomopathogenic nematodes in three Northern Districts of Tamil Nadu. Indian Journal of Entomology. 64: 288291.

Bedding, R.A.; Molyneux A.S. and Akhurst, R.J. (1983). Heterorhabditis spp., Neoaplectana spp., and Steinernema kraussei: interspecific and intraspecific differences in infectivity for insects. Experimental Parasitology. 55: 249257.

De Man, J.G. (1880). Die Einheimischen, frei in der reinen Erde und im sussen Wasser Lebende Nematoden 1: 1-104.

Devi, G.; Mishra, H.; Bhattacharyya, B. and Nath, D.J. (2016). Occurrence of entomopathogenic nematode (Rhabditida: Heterorhabditidae, Steinemematidae) in white grub infested arm of Majuli, Assam, India. Journal of Biopesticide. 9(2): 148-156.

Hazir, S.; Keskin, N.; Stock, S.P.; Kaya, H.K. and Ozcan, S. (2003). Diversity and distribution of entomopathogenic nematodes (Rhabdtida: Steinernematidae and Heterorhabdtidae) in Turkey. Biodiversity and Conservation 12(2): 375-386.

Hazir, S.; Keskin, N.; Stock, S.P.; Kaya, H.K. and Ozcan, S. (2003). Diversity and distribution of entomopathogenic nematodes (Rhabdtida: Steinernematidae and Heterorhabdtidae) in Turkey. Biodiversity and Conservation 12(2): 375-386. 
Hominick, W.M.; Reid, A.P.; Bohan, D.A. and Briscoe, B.R. (1996). Entomopathogenic nematodes: biodiversity, geographical distribution and the Convention on Biological Diversity. Biocontrol Science and Technology. 6: 317-331.

Homonick, W.M. (2002). Biogeography. In: Entomopathogenic Nematology. CAB International, Wallingford, pp. 115-143.

Hussaini, S.S.; Ansari, M. A.; Ahmad, W. and Subbotin, S.A. ( 2001). Identification some Indian populations of Steinermema species (Nematoda) by RFLP analysis of the ITS region of rDNA. International Journal of Nematology. 11(1): 73-76.

Ishibashi, N. (2002). Behaviour of entomopathogenic nematodes In: The biology of nematodes. Lee, D.L. (ed.). London, Taylor and Francis, pp. 511520.

Ivanova, T.I.; Danilov, L. and Ivakhnenko, O.A. (2000). Distribution of entomopathogenic nematodes of the families Steinernematidae and Heterorhabditidae in Russia and their morphological characteristics. Parazitologiya. 34: 323 - 334.

Kary, N.E.; Niknam, G.; Gritfrn, C.T.; Mohammadi, S.A. and Moghaddam, M. (2009). A survey of entomopathogenic nematodes of the families Steinernematidae and Heterorhabditidae (Nematoda: Rhabditida) in the Northwest of Iran. Nematology. 11(1): 107116.

Kary, N.E.; Niknam, G.; Gritfrn, C.T.; Mohammadi, S.A. and Moghaddam, M. (2009). A survey of entomopathogenic nematodes of the families Steinernematidae and Heterorhabditidae (Nematoda: Rhabditida) in the Northwest of Iran. Nematology. 11(1): 107116.

Kaya, H.K and Stock, S.P. (1997).
Techniques in insect nematology. Manual of Techniques in Insect Pathology. pp. 281-324.

Kaya, H.K. and Gaugler, R. (1993). Entomopathogenic nematodes .Annual Review of Entomology 38: 181-206.

Laznik, Z.; Toth, T.; Lakatos, T.; Vidrih, M. and Trdan, S. (2009). First record of a cold active entomopathogenic nematode Steinernema kraussei (Steiner) (Rhabditida: Steinernematidae) in Slovenia. Acta agriculturae Slovenica. 93: 37-42.

Mracek, Z.; Becvar S.; Kindlmann P. and Jersakova, J. (2005). Habitat preference for entomopathogenic nematodes, their insect hosts and new faunistic records for the Czech Republic. Biological Control. 34: 27-37.

Ngugyen, K.B and Smart, G.C. (1995). Steinernema scapterisci n. $\mathrm{sp}$. (Rhabditida: Steinernematidae). Journal of Nematology 22(2): 187.

Ngugyen, K.B and Smart, G.C. (1995). Steinernema scapterisci n. sp. (Rhabditida: Steinernematidae). Journal of Nematology 22(2): 187.

Nielsen, O. and Philipsen, H. (2003) Danish surveys on insects naturally infected with entomopathogenic nematodes. Bulletin OILB/SROP 26, 131-136.

Poinar, G.O. (1976). Description and biology of a new insect parasitic rhabditoid, Heterorhabditis bacteriophora n.gen. n.sp. (Rhabditida: Heterorhabditidae) Nematologica 21(4): 463-470.

Poinar, G.O. (1990). Taxonomy and biology of Steinernematidae and Heterorhabditidae. In: Entomopathogenic Nematodes in Biological Control. Gaugler, R. and Kaya, H.K (ed.). CRC Press: Boca Raton, Florida, pp. 23-61.

Poinar, G.O. and Georgis, R. (1990). Characterization and field application of Heterorhabditis bacteriophora 
strainHP88

(Rhabditida:

Heterorhabditidae). Revue de

Nematologie 13(4): 387393.

Poinar, G.O.J. (1976). Description and biology of a new insect parasitic rhabditoid, Heterorhabditis

bacteriophora n. gen. n. $\mathrm{sp}$. (Rhabditida: Heterorhabditidae n. fam.). Nematologica. 21: 463-470.

Poinar, G.O.J. (1976). Description and biology of a new insect parasitic rhabditoid, Heterorhabditis bacteriophora n. gen. n. sp. (Rhabditida: Heterorhabditidae n. fam.). Nematologica. 21: 463-470.

Puza, V. and Mracek, Z. (2005). Seasonal dynamics of entomopathogenic nematodes of the genera Steinernema and Heterorhabditis as a response to abiotic factors and abundance of insect hosts. Journal of Invertebrate Pathology. 89: 116-122.

Seinhorst, J.W. (1959). A rapid method for the transfer of nematodes from fixative to anhydrous glycerine. Nematologica 4(1): 67-69.

Shyamprasad, G.; Ranganath, H.R. and Singh, P.K. (2001). Occurrence of entomopathogenic nematodes in parts of South Andamans. Current Science 80: 501-502.

Sivakumar, C.V.; Jayaraj, S. and Subramanian, S. (1989). Observations on an Indian population of the entomopathogenic nematode,

Heterorhabditis bacteriophora Poinar, 1976. Journal of biological control 2: 112-113.

Smits, P.H.; Groenen, J.T. and de Raay, G. (1991). Characterization of Heterorhaditis isolate using DNA restriction fragment length polymorphism. Revue de Nematoloogie.14(3): 445-453.

Sosamma, V. K. and Rasmi, B. (2002). Survey of entomophilic nematodes in
Kerala. Indian Journal of Nematology 32(2): 184-185.

Stock, S.P.; Griffin, C.T. and Burnell, A.M. (2002). Morphological characterization of three isolates of Heterorhabditis Poinar, 1976 from the Irish group (Nematoda: Rhabditida: Heterorhabditidae) and additional evidence supporting their recognition as a distinct species. $H$. downesi $n$. sp.Systematic Parasitology. 51 (2): 95106.

Strauch, O.; Niemann, I.; Neumann, A.; Schmidt, A.J.; Peters, A. and Ehlers, R.U. (2000). Storage and formulation of the entomopathogenic nematodes Heterorhabditis indica and $H$. bacteriophora. Biocontrol 45: 483-500.

Torres-Barragan,. A.; Suazo, A.; Buhler, W.G. and Cardoza, Y.J. (2011). Studies on the entomopathogenicity and bacterial associates of the nematode Oscheius carolinensis. Biological Control 59: 123-129.

White, G.F. (1927). A method for obtaining infective nematode larvae from cultures. Science (Washington) 6(1709): 302303.

Wright,P.J (1990) .Morphological characterisation of the entomogenous nematodes Steinernema spp. and Heterorhabditis spp. (Nematoda: Rhabditida), New Zealand Journal of Zoology, 17:4, 577-585.

Zhang, C.; Liu, J.; Xu, M.; Sun, J.; Yang, S.; An, X.; Gao, G.; Lin, M.; Lai.; Lai, R.; He, Z. and Wu, Y. (2008). Heterorhabditidoides chongmingensis gen. nov., sp. Nov. (Rhabditida: Rhabditidae), a novel number of the entomopathogenic nematodes. Journal of Invertebrate Pathology 98(2): 153168.

Zhang, K.Y.; Liu, X.H.; Tan, J.; Wang, Y.; Qiao, L.; Yedid, G.; Dai, C.S.; Qiu, R.L.; Yan, X.W.; Tan, H.W.; Su, 
Z.Y.; Lai, R. and Gao, G.F. (2012).

Heterorhabditidoides rugaoensis $\mathrm{n}$. $\mathrm{sp}$.

(Rhabditida: Rhabditidae), a novel highly pathogenic entomopathogenic nematode member of Rhabditidae. Journal of Nematology 44: 348-360

Zhang, C.X.; Yang, S.Y.; Xu, M.X.; Sun, J.; Liu, H.; Liu, J.R.; Liu, H.; Kan, F.; Sun, J.; Lai, R. and Zhang, K.Y. (2009). A novel species of Serratia, family Enterobacteriaceae: Serratia nematodiphila sp. nov., symbiotically associated with entomopathogenic nematode chongmingensis Heterorhabditidoides Rhabditidae). International Journal of Systematic and Evolutionary Microbiology. 59:1603-1608

Zhang, D.X.; Yan, L.N.; Ji, Y.J.; Hewitt, G.M. and Huang, Z.S. (2009). Unexpected relationships of substructured populations in Chinese Locusta migratoria. BMC Evolutionary Biology. 9(1): 144-155.

\section{How to cite this article:}

Bharath Amuri, Gitanjali Devi, B. N. Choudhury, P. Debnath and Diganta Bora. 2020. Isolation and Identification of Heterorhabditis bacteriophora from Tea Plantation of Assam. Int.J.Curr.Microbiol.App.Sci. 9(07): 3866-3879. doi: https://doi.org/10.20546/ijcmas.2020.907.453 